\title{
ГЕОГРАФИЯ
}

УДК 91(072.8)

\section{ИСПОЛЬЗОВАНИЕ ДЕЛОВЫХ ИГР ПРИ ПОДГОТОВКЕ БУДУЩИХ УЧИТЕЛЕЙ ГЕОГРАФИИ}

\section{Л.Ю. Горшкова}

Саратовский государственный университет, кафедра физической географии и ландшафтной экологии E-mail: geogr@sgu.ru

В статье обобщен опыт трехлетней работы автора по проведению деловых игр, которые применяются при подготовке студентов географического факультета к внеклассной работе по географии. Изложены задачи и основные этапы проведения деловых игр. По каждому из этапов даны краткие методические рекомендации. Подведены итоги проделанной работы.

\section{Use of Business Games in Training of Teachers of Geography}

\section{L.Yu. Gorshkova}

In this article the author's three-year experience of carrying out business games applied in training of students of geographical department for extracurricular work on geography is summarized. The objectives and basic stages of carrying out business games are stated. Short methodological recommendations are given to each stage. The results of the carried out work are reviewed.

Современный учитель - это, прежде всего, профессионал с большой буквы. Как бы ни изменялись технологии обучения, роль учителя в его духовном влиянии на ученика не снижается. В связи с этим вопросам профессиональной подготовки будущих учителей всегда уделялось и уделяется повышенное внимание.

Однако, как показывает опыт, далеко не все выпускники географического факультета Саратовского государственного университета связывают свою дальнейшую деятельность со школой. Этому виной много причин, главные из которых - низкая зарплата учителя и наличие дополнительных возможностей трудоустройства специалистов с университетским образованием. Отдалению студентов от педагогической деятельности способствует и значительное сокращение часов их педагогической практики в школах.

Одним из способов повышения интереса студентов к педагогической работе является включение в учебный процесс спецкурсов педагогической направленности, которые помогают студентам приобрести педагогический опыт и чувство уверенности в себе.

К числу основных направлений повышения качества учебно-воспитательного процесса относятся его интенсификация и оптимизация, предполагающие внедрение форм, методов и средств активного обучения. Требования интенсификации и оптимизации являются основополагающими и в вузе. Поэтому большую роль в учебном процессе студентов приобретает применение метода моделирования и анализа педагогических ситуаций в рамках деловых (педагогических) игр.

В педагогическом энциклопедическом словаре [1, с.61] деловая игра определена как форма воссоздания предметного и социального содержания профессиональной деятельности, моделирования систем отношений, характерных для данного вида практики.

Методические аспекты деловых игр рассматриваются в работах В.Р. Прауде [2], А.А. Вербицкого [3], Д.Н. Кавтарадзе [4, 5], В.Л. Бабурина [6], Н.В. Тельтевской [7], А.В. Дружкина, Е.В. Бердновой, В.П. Корсунова [8] и многих других.
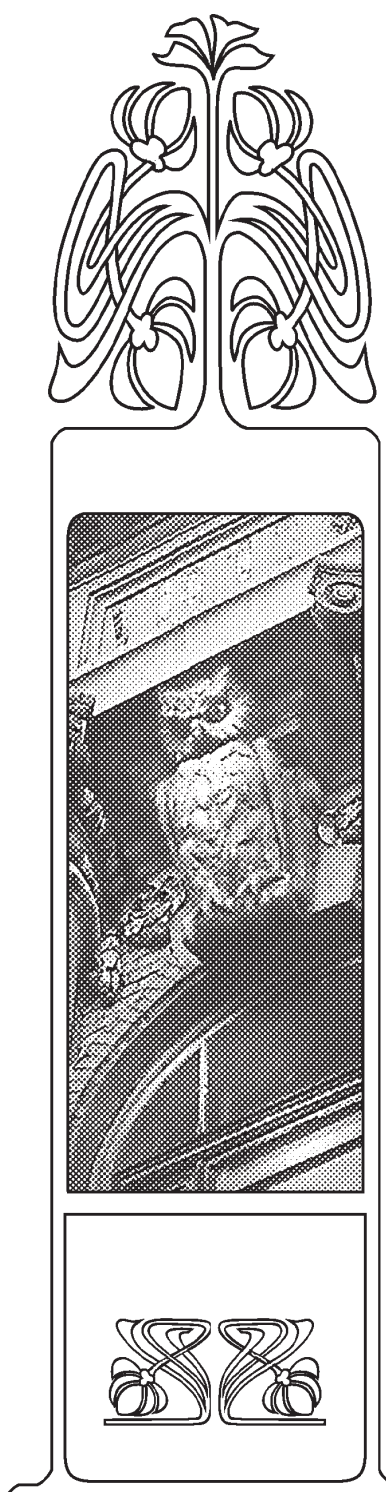

НАУЧНЫЙ
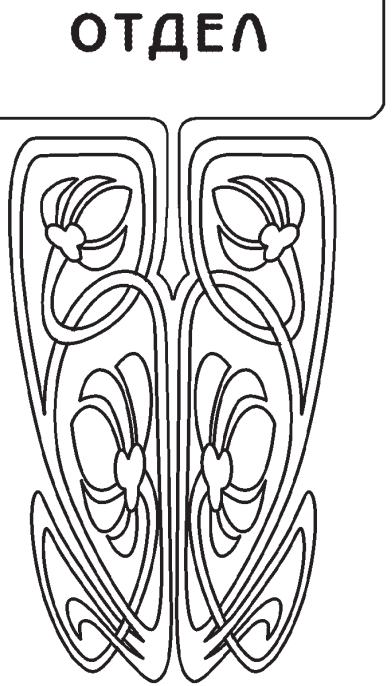
Суть этих игр состоит в имитации реальных или условных ситуаций и процессов, позволяющих, в данном случае студентам, на основе коллективного взаимодействия вырабатывать решения и приобретать профессиональные умения и опыт межличностного общения [7]. По утверждению В.Р. Прауде [2], деловые игры носят синтетический характер, т.е. вбирают в себя целый ряд особенностей активных методов обучения. Важно, чтобы воспроизведение деятельности будущих специалистов происходило с максимальным приближением к действительности. Однако, как отмечает А.А. Вербицкий [3], применение деловых игр имеет как позитивную, так и негативную стороны. Позитивная состоит в том, что подтверждаются возможности деловых игр как инструмента формирования личности профессионала, кроме того, достигается цель активизации учебного процесса. Игровой момент не только способствует возникновению интересов, но и восстанавливает эмоциональную уравновешенность участников игры. Отрицательные последствия возникают в тех случаях, когда деловая игра опирается не на психолого-педагогические или научно-методические основы, а лишь на ее внешнюю форму.

Игровая деятельность занимает существенное место и в психическом развитии личности, поскольку игропрактика в целом, а игромоделирование в форме «организационно-деятельностных игр» в особенности, дают богатый материал для анализа процесса осуществления принципиальных переосмысливаний человеком своего места в жизни, образа жизни и смысла жизни [9].

В нашей стране и за рубежом общепринятая концепция деловой игры все еще недостаточно разработана. Организаторам деловых игр необходимо помнить о том, что по своей природе эти игры отвечают потребностям студентов применить свои знания на практике, пусть даже модельной, научиться получать первичную информацию о проблеме и строить умозаключения самостоятельно [2, 3].

В течение последних трех лет на кафедре физической географии и ландшафтной экологии в преддверии педагогической практики в рамках спецкурса «Внеклассная работа по географии в системе экологического воспитания» проводится серия деловых игр со студентами IV курса. Основными задачами их проведения являются:

1) закрепление теоретических знаний, полученных при чтении лекций по данному спецкурсу;

2) обучение студентов организации внеклассных мероприятий по географии на научно-педагогической основе;

3) развитие у будущих специалистов педагогического мышления и педагогических способностей;

4) формирование у студентов умений и навыков для проведения внеклассной работы на педагогической практике и после окончания университета;

5) развитие их педагогической культуры.

Организация проведения деловых игр состоит из нескольких этапов.

Первый этап - подготовительный. О проведении деловых игр студенты ставятся в известность на первом занятии по спецкурсу, примерно за два с половиной месяца. В течение всего этого времени студенты думают над темой и формой проведения своего мероприятия, подбирают соответствующую литературу, получают необходимую консультацию у преподавателя. В выборе формы внеклассного занятия студентам предоставляется полная свобода действий, тем не менее необходимость разнообразия форм проведения оговаривается заранее. Обязательным условием служит проведение деловой игры каждым студентом. В период ее подготовки происходит определение целей игры, выбор ситуации с соблюдением правдоподобия и уровня сложности, поскольку она должна соответствовать возрастным особенностям ее участников. В подготовительный этап входит и разработка правил игры, в которых учитывается, что разрешается делать игрокам и ведущему, определяется роль каждого играющего, описывается, как нужно истолковывать те или иные возникающие ситуации, устанавливаются моменты начала и окончания игры и т.д.

Bторой этап - основной - проведение игры. Данное мероприятие не должно проходить менее 40 минут. Отметим, что методика проведения игры не является жесткой и предполагает поощрение самовыражения как отдельного студента, так и группы в целом.

Заключительный этап - анализ проведения uгры. Перед началом анализа студентам-ведущим, представляющим учителей географии, задается ряд вопросов. Например: 1. Чем была обусловлена ситуация, в которой Вы использовали именно эту игру (содержанием учебного материала, дидактическими задачами, ситуацией, связанной с усиленным вниманием к воспитательным задачам и т.д.)? 2. Какой игровой результат Вы хотели получить в ходе и/или по окончанию игры?

Далее каждому студенту предлагается обозначить по одному на их взгляд отрицательному, а затем по одному положительному моменту игры. Иногда, на данном этапе, точки зрения студентов существенно расходятся, и возникает дискуссия, навыки ведения которой студентам также необходимо развивать. Как правило, оставляет желать лучшего операционно-коммуникативный компонент дискуссии, включающий умение вести спор, отстаивать свою точку зрения, владеть способами осуществления логических операций. Поэтому на данном этапе ведущая роль принадлежит методисту, который помогает студентам не только систематизировать материал, мысли и идеи, высказанные участниками игры, определить, чему они 
научились, но и корректно разрешить возникшую проблемную ситуацию. Иногда рассматриваемый вопрос может остаться открытым. Важно, чтобы студенты высказали свои соображения и осознали сложность решения проблемы.

После проведения игры студенты составляют письменный отчет, состоящий из плана-конспекта игры, ее цели и задач, методических указаний по проведению, а также выводов, сделанных по результатам проведения игры.

Занятия проводятся таким образом: первый час - игра, второй час - ее анализ. По характеру моделируемых ситуаций подобного рода деловые игры можно отнести к играм-тренировкам. В них моделируется процесс управления в динамике самопроизвольного развития ситуации, а также отрабатываются навыки в принятии оперативных решений. По характеру игрового процесса - это игры-взаимодействия, поскольку разыгрывается взаимодействие между участниками игры (группами). Здесь контакт с помощью различных видов (средств) связи является обязательным элементом игры. По способам передачи и обработки информации - игры с применением обычных средств связи и обычных носителей (текстов, схем, рисунков и т.д.). По динамике моделируемых процессов педагогические деловые игры могут быть как с ограниченным числом ходов, так и саморазвивающиеся. По учету времени моделирования - игры с масштабом времени.

Приведем пример деловой игры по теме «Методика проведения ролевой игры на занятии географического кружка». Цель: отработать методику проведения ролевой игры в кружковой работе.

Ход игры. Ролевая игра носит название «На необитаемом острове». Ответственный за игру «учитель» рассказывает в 5-7-минутном сообщении об основных правилах проведения мероприятия. Затем делит участников на группы - «экспедиции», руководствуясь (по выбору) либо их успеваемостью, либо их малой общительностью друг с другом, либо их разнополостью, либо их собственными желаниями. Каждая «экспедиция» состоит из «начальника экспедиции - географа», «картографа», «биолога», «метеоролога». После чего «учитель» обрисовывает ситуацию, в которую попадают команды. Отправляясь в так называемое кругосветное путешествие команды терпят кораблекрушение и попадают на необитаемый остров в Тихом океане. Каждая из «экспедиций» оказалась в разных частях острова. На данном этапе команды получают конверты с заданиями для каждого «специалиста». «Начальник экспедиции» помогает им в выполнении заданий и следит за дисциплиной.

Задание картографам: известно, что корабль начал терпеть крушение в районе $12^{\circ}$ с.ш., $160^{\circ}$ в.д. К тому моменту, как он окончательно ушел под воду, вы оказались на $3^{\circ}$ западнее, здесь вы пересели на шлюпку и переместились на $7^{\circ}$ к югу. Все было неплохо, пока вас не подхватило течением и не унесло на $13^{\circ}$ к востоку. Определите по карте местонахождение необитаемого острова (его географические координаты). К группе каких островов он принадлежит? Какое течение «помогло» вам сюда добраться? Проконсультируйтесь с географом.

Задание метеорологам: проконсультируйтесь с картографом и географом и дайте краткую характеристику климату данного острова по тематическим картам атласа: определите климатический пояс, тип воздушных масс, температурные условия, количество атмосферных осадков, установите тип климата.

Задание биологам: проконсультируйтесь с метеорологом и географом вашей группы, определите, к какой природной зоне относится ваш остров, установите, как растения и животные приспособились к данным природным условиям, составьте перечень их многообразия.

После окончания работы все листочки с вопросами и ответами на них вкладываются обратно в конверты и сдаются «учителю» для проверки.

На следующем этапе командам предлагается создать общину, самостоятельно придумать и распределить в ней свои роли. На обсуждение дается 1-2 мин, после чего ребята делятся своими решениями. Затем участникам необходимо выложить все имеющиеся у них вещи на стол, выбрать любые три, которые могут пригодиться на «острове», и придумать для этих предметов функции, не свойственные им в действительности. После 2-минутного обсуждения ребята рассказывают о своих решениях. Потом каждой команде раздаются чистые листы бумаги и одинаковые наборы цветных карандашей и дается задание нарисовать свой лагерь и общину. Ребята на листе рисуют по очереди, каждый из «членов общины» должен нарисовать всего один объект или какуюлибо деталь, причем молча. Содержание рисунка, его цветовая гамма, а также размеры отдельных деталей позволяют сделать выводы о слаженности работы в каждой группе и отдельных чертах характера ее участников. Для выполнения этого задания дается 2 мин и затем идет обсуждение нарисованного.

Далее ребятам предлагается следующая ситуация: члены лагеря в очередной раз выходят на охоту и сталкиваются с членами другого лагеря. Что делать? Если ситуация зашла в тупик, «учитель» может предложить сходить им друг к другу в гости, но при условии, что от каждого лагеря пойдет один представитель и возьмет подарок из тех трех предметов, которые были выбраны в начале игры. Результат может быть неожиданным: ребята могут вообще не пойти в гости, а могут посетить сразу две команды.

После этого задания участникам обрисовывается следующая ситуация: прошло несколько лет, вдруг на горизонте появился корабль. Како- 
вы ваши действия? Команды обсуждают и дают свои варианты ответов. Результаты также бывают разными. Если какая-то команда решает покинуть остров, то ей предлагается оставить записку для других общин, текст которой потом анализируется при обсуждении. В конце «учитель» выясняет, понравилось ли это путешествие участникам, если да, то чем, если нет, то почему; подводит итог мероприятия.

На втором часе «учитель» вместе со студентами анализирует игру, а методист, как было сказано выше, подводит окончательные итоги. Студенты приходят к выводу, что проведенная ролевая игра носит отчасти психолого-педагогический характер и ее применение целесообразно на начальной стадии работы географического кружка с целью не только проверки уровня знаний, но и более близкого знакомства детей из разных классов, с целью выявления особенностей характера ребят, а также умений школьников работать в коллективе, находить выход из неожиданных ситуаций. Все это необходимо учителю для эффективности работы кружка в дальнейшем.

Данная игра опирается на систему знаний, в которую составными элементами входят знания по географии, педагогике, психологии, методике преподавания географии. В процессе усвоения системы знаний, утверждает Н.В. Тельтевская [10], у студентов формируется способность творчески применять эти знания в конкретных ситуациях и находить оптимальное решение, т.е. происходит формирование профессионального типа мышления, без которого немыслимо становление будущего специалиста.

В рамках деловых игр проходят занятия по отработке методики проведения географических КВН, викторин, фрагментов факультативных и кружковых занятий и других форм внеклассной работы по географии. Как показывает практика, при выборе форм внеклассных занятий студенты отдают предпочтение викторинам и КВН. По-видимому, потому, что они отличаются универсальностью применения, так как могут включаться в планы работы географических кружков, в программы проведения географических вечеров, утренников, т.е. легко могут использоваться как при групповых, так и при массовых видах внеклассной работы. Так, за три года проведения деловых игр студентами было представлено 63,7\% викторин и КВН, $18,2 \%$ фрагментов факультативов, $9,1 \%$ ролевых игр и по 4,5\% таких форм занятий, как лекция и экскурсия. Для отработки методики проведения краеведческих олимпиад, географических пресс-конференций, внеклассного чтения по географии и других форм, мало используемых студентами самостоятельно, методисту необходимо самому назначать ответственных «учителей» за подготовку и проведение учебных занятий с включением в их процесс данных форм.

Применение методики деловых игр при подготовке студентов к внеклассной работе по географии открывает большие возможности для их самостоятельной работы, повышает интерес студентов к педагогической деятельности и к самому процессу вузовского обучения. Кроме того, как справедливо отмечает Н.В. Тельтевская [7], позволяет им чувствовать себя субъектами, а не объектами деятельности в учебном процессе.

\section{Библиографический список}

1. Педагогический энциклопедический словарь / Гл. ред. Б.М. Бим-Бад; Редкол.: М.М. Безруких, В.А. Болотов, Л.С. Глебова и др. М.: Большая Российская энциклопедия, $2003.528 \mathrm{c}$

2. Прауде В.Р. Применение деловых игр в учебном процессе: Учеб. пособие. Рига: ЛГУ им. П.Стучки, 1985. $75 \mathrm{c}$.

3. Вербицкий А.А. Активное обучение в высшей школе: контекстный подход: Метод. пособие. М.: Высш. шк., 1991. $207 \mathrm{c}$.

4. Кавтарадзе Д.Н. «Координационная комиссия»: Учебно-имитационная игра по охране окружающей среды (учеб. пособие к курсу «Биосфера и человек»): В 2 ч. М., 1981. Ч. $1.20 \mathrm{c.}$

5. Там же. Ч. 2.25 с.

6. Бабурин В.Л. Деловые игры по экономической и социальной географии: Кн. для учителя. М.: Просвещение, 1995. $141 \mathrm{c}$.

7. Тельтевская Н.В. Формирование системы профессионально-педагогических знаний. Теоретический аспект. Саратов: Изд-во Сарат. ун-та, 2002. 127 с.

8. Профессиональные игры в педагогической интерпретации: Учеб. пособие / А.В. Дружкин, Е.В. Берднова, В.П. Корсунов. Саратов: Изд-во Сарат. ун-та, 2001. 34 с.

9. Анисимов О.С. Смысл жизни и опыт самоопределения в игромоделировании // Мир психологии. 2000. № 4. C. $121-126$.

10. Тельтевская Н.В. Развитие познавательных интересов будущих учителей / Подготовка учителей в вузе. Саратов: Изд-во Сарат. ун-та, 1992. С. 21-24. 